\title{
The suitability of polish ortho-lignite deposits for clean coal technologies
}

\section{Introduction}

The share of hard coal and lignite in the world's energy resources is $64 \%$, while, the share of crude oil and natural gas is $18 \%$ each. Given that, coal is the world's largest primary energy source. As of 2013, Poland is the fourth largest producer of lignite behind Germany, Russia and the United States (WCA 2015; IEA 2015).

Polish lignite is almost exclusively processed in order to produce electricity and heat. Only small amounts on the market are addressed for municipal purposes and heating. The same applies to lignite used in agriculture as an organic fertilizer. Currently, the production of electricity and heat is the only large scale use for lignite in Poland. Any other possibilities of using this raw material, primarily for chemical processing and synthesis gas production, are ignored.

The annual production capacity of polish lignite mines is around 66 million tons of coal, almost exclusively used for electricity and heat production. The installed capacity of lignite-fired power plants is around 9,000 MW, while the produced energy has $34 \%$ share in domestic production. The aforementioned energy is $30 \%$ cheaper than energy from hard coal (Kasztelewicz et al. 2013).

Currently, lignite is mined in the following mines:

- Lignite Mine Adamów - 2 open pits, the annual production capacity of 5 million tons,

* Ph.D. Eng., AGH University of Science and Technology, Krakow, Poland; e-mail: bbiel@agh.edu.pl 
- PGE GiEK, Lignite Mine Bełchatów and Lignite Mine Turów - 3 open pits, the annual production capacity of 51.3 million tons,

- Lignite Mine Konin - 3 open pits, the annual production capacity of 10.4 million tons.

With no new open pits exploited, the year 2040 will mark the end of lignite mining in Poland. However, there are ongoing efforts aimed at exploitation of the Legnica, Złoczew and Gubin deposits. Based on an analysis, the production capacity after opening prospective deposits increases to around 110 million tons by 2040 (Tajduś et al. 2011).

\section{Clean Coal Technologies in Poland}

The EU's energy policy and the need to reduce $\mathrm{CO}_{2}$ emissions in Poland were the driving force behind several projects focusing on underground and surface gasification aimed at energy production.

The National Centre for Research and Development project: „The development of coal gasification technology for highly efficient production of fuels and electricity" by the consortium including the Central Mining Institute in Katowice, the Institute for Chemical Processing of Coal, the Silesian University of Technology in Gliwice and industrial entities: Tauron Group, KGHM Polska Miedź and the Azoty Group is led by the AGH University of Science and Technology. The project addresses the need of extending the use of coal using the eco-economical methods for obtaining certain economically useful products.

They are several different technologies for gasification of solid fuels. The used reactor designs can be classified into three main types: moving bed, fluidized bed, entrained flow (Higman and van der Burgt 2008).

In the case of lignite gasification, the most promising technological solutions allowing achieving high conversion efficiency at high system efficiency are fluidized bed reactors. Fluidized bed gasification involves the administration of fine grades into the stream of gasification agents, causing simultaneous fluctuation The fuel stays in the reactor at a temperature of $900-1050^{\circ} \mathrm{C}$ for about $10-100 \mathrm{~s}$, and, as a result, the lignite is not completely gasified. Therefore, the unreacted particles of coal are recovered from the resulting syngas using cyclones and then are subjected to recycling (Bielowicz 2013a).

An example of fluidized bed gasification of coal is the circulating fluidized bed gasification using carbon dioxide carried out by the Institute for Chemical Processing of Coal. The attractiveness of the concept results from the use of carbon dioxide as gasifying agent, supplying carbon ( $\mathrm{C}$ element $)$ and oxygen to the system, which improves the process efficiency (increased flow of chemical enthalpy of the process gas, decrease in oxygen consumption) and reduce the relative carbon dioxide emissions (Chmielniak et al. 2015). The results obtained for lignite gasification indicate high usefulness of this raw material in syngas production. 
One of the key tasks of the national project is to explore the possibility of underground gasification of lignite in Poland. For this purpose, the Central Mining Institute carried out an experiment at the Experimental Mine Barbara in Mikołów (GIG). The lignite from the Turów Lignite Mine was subjected to ex-situ gasification in the reactor.

The lignite sample for gasification in reactor with a length of almost $6.7 \mathrm{~m}$, including a simple type fire channel at the Experimental Mine Barbara was gasified for a period of 120 hours with oxygen as gasifying agent (Kapusta et al. 2014). The average composition, calorific value and the volume flow of gases produced during the ex-situ gasification is shown in Table 1.

Table 1. Average gas composition and calorific values of product gas in oxygen gasification of Turów lignite seam (Kapusta et al. 2014)

Tabela 1. Średni skład oraz wartość opałowa gazu produkowanego w trakcie próby Turów (Kapusta i in. 2014)

\begin{tabular}{|c|c|c|c|c|c|c|c|c|c|}
\hline \multirow{2}{*}{ Test } & \multirow{2}{*}{$\begin{array}{l}\text { Time } \\
{[\mathrm{h}]}\end{array}$} & \multirow{2}{*}{$\begin{array}{c}\text { Gas } \\
\text { production } \\
{\left[\mathrm{Nm}^{3} / \mathrm{h}\right]}\end{array}$} & \multicolumn{6}{|c|}{ Composition [\%vol.] } & \multirow{2}{*}{$\begin{array}{c}\mathrm{WO} \\
{\left[\mathrm{MJ} / \mathrm{m}^{3}\right]}\end{array}$} \\
\hline & & & $\mathrm{CO}_{2}$ & $\mathrm{H}_{2}$ & $\mathrm{O}_{2}$ & $\mathrm{~N}_{2}$ & $\mathrm{CH}_{4}$ & $\mathrm{CO}$ & \\
\hline Pressureless & 120 & 8.0 & 45.3 & 29.8 & 0.2 & 3.7 & 5.2 & 15.5 & 7.2 \\
\hline
\end{tabular}

The maximum temperatures measured in the deposit during the Turów test were around $900^{\circ} \mathrm{C}$ and were observed at $0.3 \mathrm{~m}$. above the floor, in the vicinity of the area where oxygen is fed to the reactor. On the basis of the temperature data, two dimensional temperature profiles in longitudinal section of the deposit were developed. On the basis of the temperature data, two dimensional temperature profiles in longitudinal section of the deposit were created. The analysis of obtained images allows tracking the development of gasification process and the development of the cavern over the time of the process. The gasification speed and the amount of gas produced were also assessed during the test (Table 2).

Table 2. Selected energy parameters for the gasification experiment Turów (Kapusta et al. 2014)

Tabela 2. Wybrane parametry energetyczne charakteryzujące próbę zgazowania Turów (Kapusta i in. 2014)

\begin{tabular}{|c|c|c|c|c|}
\hline Test & $\begin{array}{c}\text { Stage/gasifying agent } \\
{\left[\mathrm{Nm}^{3} / \mathrm{h}\right]}\end{array}$ & $\begin{array}{c}\text { The amount of gasified } \\
\text { coal }[\mathrm{kg}]\end{array}$ & $\begin{array}{c}\text { Gasification } \\
\text { speed }[\mathrm{kg} / \mathrm{h}]\end{array}$ & $\begin{array}{c}\text { Gas production } \\
\mathrm{Nm}^{3} / \mathrm{kg}_{\text {of }} \text { coal }\end{array}$ \\
\hline Pressureless & Oxygen & 946.5 & 7.9 & 1.0 \\
\hline
\end{tabular}

Experimental oxygen gasification of lignite in pressure free conditions has shown the ability to continuously obtain gas with a relatively high calorific value $\left(7.2 \mathrm{MJ} / \mathrm{Nm}^{3}\right)$ and gross energy efficiency around 59\% (Kapusta et al. 2014). 


\section{Possibilities of using lignite gasification in Poland}

One of the key elements in this study, is a detailed diagnosis of the resource base, its analysis on the basis of the established verification criteria (the Institute for Chemical Processing of Coal) and - as a result - the achievement of a reliable assessment of suitability for highly efficient production of fuels and electric energy through lignite gasification in both surface and underground installations, taking into account both sozological conditions and protected geological sites.

The lignite deposits in Poland are genetically related with the Tertiary formations covering large areas on the Polish-German Lowlands, that is areas north of the the Holy-Cross Mts, the Miechów Synclinorium and the Sudetes Mts.

They continue to the west, across the Polish-German border, in the eastern Germany up to the Lusatian Mountains the Ore Mountains and the Harz. Towards the east, in the direction of Podlasie, Belarus and Ukraine, they are gradually wedging-out. The areas of largest industrial significance (the largest number of coal deposits, including those of major mining and economic importance) are located in Poland (west of the Cuiavian-Pomeranian ridge) and in eastern Germany (Lausitz, Branderburg, Saxony). These areas are dominated by large scale lignite mining activities (numerous German open pits near Cottbus, Hoyerswerda, Senftenberg, Leipzig and Halle.

Paleogene and Neogene coal-bearing formations are horizontally layered on older formations mainly Mesozoic and Paleozoic formations. Their thickness varies from tens of meters to the east and south, up to $500 \mathrm{~m}$ in graben and larger tectonic subsidences. In addition to generally poorly cohesive, very often loose rocks, there are 10 groups of lignite deposits (Fig. 1, Table 3), sometimes of considerable thickness. The maximum thicknesses were observed in the area of Kleszczów Trough (up to 150 meters of pure lignite in Bełchatów deposit), in Turów (former Turów I open pit), near Legnica and in the Poznań Tectonic Trough. The deposits with large lignite resources were documented in all of the aforementioned areas. The majority of deposits are located shallow below the surface, while exploited industrial deposits are not deeper than $200 \mathrm{~m}$. This favors open cast mining and achieving high production with almost no loss of raw material (below $10 \%$ ).

The most economically important deposits $\left(1^{\text {st } \_} 4^{\text {th }}\right)$ are located in the Miocene profile. Three upper deposits $\left(1^{\text {st }}-3^{\text {rd }}\right)$ are exploited in the existing opencast mines and also provide a base for further expansion of the mining industry in new deposits (perspective deposits). Part of lignite reserves from these deposits can be used for gasification in chemical plants.

The following geological and reservoir areas can be distinguished in the area of occurrence of the Tertiary coal-bearing formation:

- Western region (A) - the area along the Polish-German border, including the following deposits: Cybinka, Gubin-Brody and Mosty (perspective deposit);

- North region (B);

- The Legnica region (C) - the Legnica West, East and North deposit; Ruja Ścinawa, Ścinawa-Głogów (favorable development perspectives); 


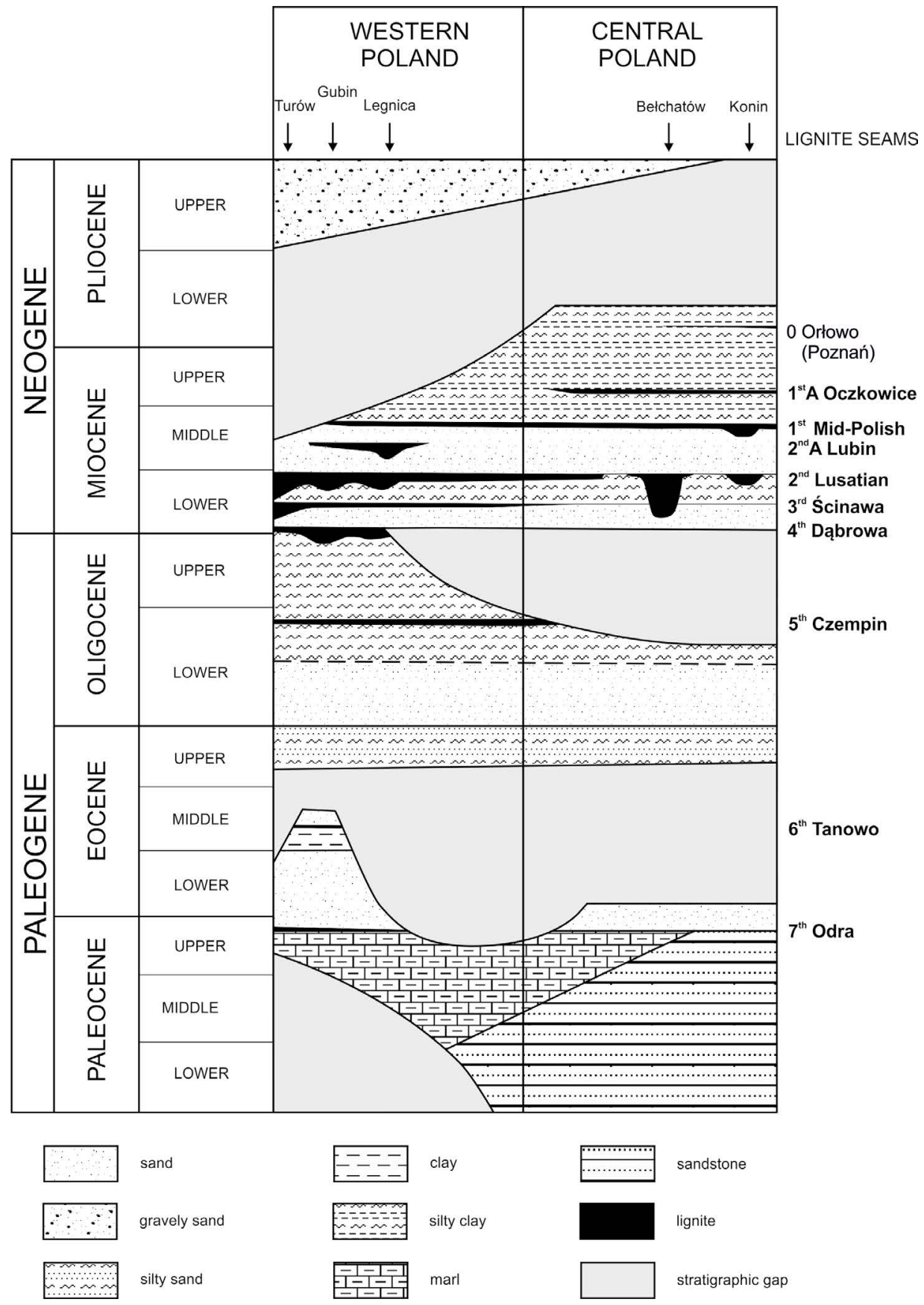

Fig. 1. Paleogene and Neogene stratigraphic column in the Polish Lowland (according to Kasiński et al. 2010, modified)

Fig. 1. Stratygrafia pleogenu i neogenu na Niżu Polskim (według Kasiński i in. 2010, zmodyfikowane) 
- The Radom region (D) - Local, single seam deposits of minor importance;

- The Konin region (E) - single seam deposits in the Konin-Turek area;

- The Łódź region (F) - lignite seams overlying salt deposits;

- The Bełchatów region $(\mathrm{G})$ - considerable lignite thickness, large reserves, intensive mining activities;

- The Wielkopolska region (H) - large reserves in the Poznań Tectonic Trough.

Table 3. Characteristics of lignite deposits in Poland

Tabela 3. Charakterystyka pokładów węgla brunatnego w Polsce

\begin{tabular}{|c|c|c|c|c|c|c|}
\hline \multicolumn{3}{|c|}{ Timescale } & \multicolumn{3}{|c|}{ Localization of lignite deposits } & \multirow{2}{*}{$\begin{array}{l}\text { Maximum } \\
\text { thickness }\end{array}$} \\
\hline & & & $\begin{array}{l}\text { no group of } \\
\text { lignite seam }\end{array}$ & name of group seam & importance & \\
\hline \multirow{7}{*}{ 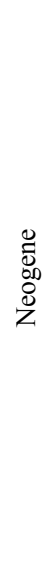 } & \multicolumn{2}{|c|}{ Pliocene } & 0 & Poznań (Orłowo) (O-0) & non industrial & lenses \\
\hline & \multirow{6}{*}{ Miocene } & upper & $1^{\text {st }} \mathrm{A}$ & Oczkowice & non industrial & $\begin{array}{c}\text { up to } 2 \mathrm{~m} \text {, } \\
\text { lenses }\end{array}$ \\
\hline & & \multirow[t]{2}{*}{ middle } & $1^{\text {st }}$ & Middle-Polish (MPLS-1) & $\begin{array}{l}\text { eg. Adamów, Pątnów, } \\
\text { Koźmin, Tomisławice, } \\
\text { Dęby Szlachecki }\end{array}$ & up to $15 \mathrm{~m}$ \\
\hline & & & $2^{\text {nd }} \mathrm{A}$ & Lubin & non industrial & lenses \\
\hline & & \multirow{3}{*}{ lower } & $2^{\text {nd }}$ & Lusatian (LLS-2) & $\begin{array}{l}\text { Bełchatów, Turów, } \\
\text { Legnica, Gubin, Cybinka, } \\
\text { Poznań Trough }\end{array}$ & $150 \mathrm{~m}$ \\
\hline & & & $3^{\text {rd }}$ & Ścinawa (ŚLS-3) & Bełchatów, Turów & av. $20 \mathrm{~m}$ \\
\hline & & & $4^{\text {th }}$ & Dąbrowa (DLS-4) & non industrial & up to $20 \mathrm{~m}$ \\
\hline \multirow{7}{*}{ 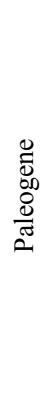 } & \multirow{2}{*}{ Oligocene } & upper & & & & \\
\hline & & lower & $5^{\text {th }}$ & Czempiń (CLS-5) & non industrial & several $\mathrm{m}$ \\
\hline & \multirow{3}{*}{ Eocene } & upper & & & & \\
\hline & & middle & $6^{\text {th }}$ & Tanowo (TLS-6) & non industrial & several $\mathrm{m}$ \\
\hline & & lower & & & & \\
\hline & \multirow{2}{*}{ Paleocene } & upper & $7^{\text {th }}$ & Odra (OLS-7) & non industrial & several $\mathrm{m}$ \\
\hline & & lower & & & & \\
\hline
\end{tabular}

\subsection{The possibility of underground gasification}

The process of underground lignite gasification has not yet been started or technologically mastered in Poland. A number of research projects focused on the state of the resource 
base suitable for underground gasification and on the possible limitations for this process resulting from very different conditions, including: geological structure of deposits, the presence of useful raw materials (e.g. Major Groundwater Reservoirs), environmental protection requirements and protecting the system against the escape of harmful gases, etc. The subject is very broad and complex.

The countries interested in the use of lignite reserves that are difficult for exploitation using traditional methods have been carrying out underground coal gasification (UCG) for many years.

The Polish lignite deposits for underground gasification must fulfill a number of criteria, which take into account geological, localization, infrastructure, sozological (nature protection), legal and social conditions of a given area. Table 4 shows the criteria for underground gasification of lignite.

The following morphological types of Polish lignite deposits, regardless of their original genesis and form, are distinguished:

- seams,

- lenticular deposits,

- relic deposits,

- deposits overlying salt domes,

- tectonic deposits,

- glaciotectonic deposits.

Table 4. Classification criteria for lignite deposits for underground gasification processes (according Bielowicz and Kasiński 2014; Nowak et al. 2011)

Tabela 4. Kryteria dopuszczające złoża do zgazowania podziemnego (według Bielowicz i Kasiński 2014, Nowak i in. 2011)

\begin{tabular}{|c|c|c|}
\hline No. & Criterion & Range of variability \\
\hline \multirow{6}{*}{1.} & \multicolumn{2}{|c|}{ Type of coal and physicochemical parameters: } \\
\hline & - calorific value & minimum amount not specified (from $6.5 \mathrm{MJ} / \mathrm{kg}$ ) \\
\hline & - volatile matter & below $50 \%$ \\
\hline & - ash content & below $20 \%$ optionally $25 \%$ \\
\hline & - natural moisture & below $55 \%$ \\
\hline & - sulfur content & below $4.0 \%$ \\
\hline \multirow{3}{*}{2.} & \multicolumn{2}{|l|}{ Deposit thickness: } \\
\hline & - minimal & $2 \mathrm{~m}$ up to $4 \mathrm{~m}$ (optimal) \\
\hline & maximum & $\begin{array}{l}\text { dependent on hydraulic insulation, overall conservation and the } \\
\text { conservation of the boreholes (controlling overburden collapse) }\end{array}$ \\
\hline
\end{tabular}


Table 4. cont.

Tabela 4. cd.

\begin{tabular}{|c|c|c|}
\hline No. & Criterion & Range of variability \\
\hline \multirow[b]{2}{*}{3.} & \multicolumn{2}{|l|}{ Depth: } \\
\hline & - minimal & $\begin{array}{l}\text { over } 150 \mathrm{~m} * \text { - below erosion washouts and glacitectonic channels. } \\
\text { In case of the deposits not associated with glacial activity, } \\
\text { the depth may be lower }\end{array}$ \\
\hline \multirow{3}{*}{4.} & \multicolumn{2}{|l|}{ Deposit type: } \\
\hline & - single-seam deposit & preferred \\
\hline & - multi-seam deposit & $\begin{array}{l}\text { possible when using advanced technology (e.g. using backfill), } \\
\text { the distance between seams }>20 \mathrm{~m}\end{array}$ \\
\hline 5. & Overburden ratio: & $>12$ (10) roof of the deposit at a depth of up to $350 \mathrm{~m}^{* *}$ \\
\hline 6. & Inclination angle of the deposit & horizontal or slightly inclined \\
\hline 7. & $\begin{array}{l}\text { Thermal insulation of the surrounding } \\
\text { rocks }\end{array}$ & $\begin{array}{l}\text { roof rocks are clays and silts of very low permeability } \\
(\mathrm{k} \leq 9 \cdot 10-8 \mathrm{~m} / \mathrm{s}) \text { with a thickness of } \geq 10-20 \mathrm{~m} \\
2.8 \text { of deposit thickness } * *\end{array}$ \\
\hline \multirow{3}{*}{8.} & \multicolumn{2}{|l|}{ The hydrogeological conditions: } \\
\hline & position in relation to aquifer & $\begin{array}{l}\text { below the usable aquifers and outside the Major Groundwater } \\
\text { Reservoirs, the minimum distance is } 40 \mathrm{~m}\end{array}$ \\
\hline & - volume of water flow to the seam & below $2 \mathrm{~m}^{3} / \mathrm{Mg}$ of lignite without additional draining \\
\hline 9. & Tectonics & $\begin{array}{l}\text { no cracks and faults, no significant tectonic disturbances within } \\
\text { the mining fields }\end{array}$ \\
\hline 10. & The porosity of the surrounding rocks & $\begin{array}{l}\text { roof rocks and the floor rocks should have lower gas permeability } \\
\text { than lignite seam, while the thickness of poorly permeable rocks } \\
\text { surrounding the seam should be } 1-2 \text { meters or } 2-4 \text { meters for } \\
2 \text { meters and } 3-10 \text { meters of seam thickness, respectively** }\end{array}$ \\
\hline 11. & The amount of reserves & $\begin{array}{l}\text { reserves required for pilot plant are around } 75-450 \text { thousand } \mathrm{Mg} \text {, } \\
\text { while commercial project will need a minimum of } 3.5 \mathrm{Mt} * *\end{array}$ \\
\hline 12. & Filtration properties of the rock & $\begin{array}{l}\text { the ratio of porosity of lignite seam to that of surrounding rocks } \\
\text { should not be less than } \mathrm{mD} 18: 20^{* *}\end{array}$ \\
\hline & & epending on location \\
\hline 13. & $\begin{array}{l}\text { The area required for underground } \\
\text { lignite gasification plant }\end{array}$ & $\begin{array}{l}\text { minimal area for the pilot plant is } 50-100 \text { ha }\left(0.5-1 \mathrm{~km}^{2}\right) \text {, } \\
\text { while for the commercial installation it is over } 100 \text { hectares** }\end{array}$ \\
\hline 14. & Safety conditions & $\begin{array}{l}\text { minimum distance from: residential areas }(1-3 \mathrm{~km}) \text {, } \\
\text { rivers and lakes }(1-3 \mathrm{~km}) \text {, protected areas }(5 \mathrm{~km}) \text {, currently exploited } \\
\text { mines } / \text { mining areas }(5 \mathrm{~km}) \text {, abandoned mines/workings }(3 \mathrm{~km}) \text {, } \\
\text { transmission lines and railways }(1-3 \mathrm{~km})^{* *}\end{array}$ \\
\hline
\end{tabular}

* In specific cases - including no glacial activity - conditions may be less restrictive.

** Criteria according to Nowak et al. 2011. 
The seams occur mainly in south-western Poland, in the western part of the Fore-Sudetic Monocline. Other Miocene coal-bearing areas are dominated by lenses of different sizes, ranging from very small to large, for example the Konin, Adamów, Oczkowice and other deposits, as well as relic deposits, for example the Ochle deposit near Konin. In terms of suitability for the gasification process, single seam lenticular or widespread deposits are preferred.

Coal deposits occurring in salt domes are associated with morphological surface depressions of gypsum cap, although their borders are often defined by the Mesozoic formations, through which the salt diapir was squeezed upwards. These include the Rogoźno deposit north of Łódź, as well as Lubień and Łanięta deposits in the Kujawy region. The most abundant lignite deposits are located in tectonic valleys. Until now, several deposits of this type were confirmed. They are located mainly on the NW-SE or the NS - these include deposits from the Poznań group (Mosina, Czempin, Krzywin, Gostyń), Szamotuły and Nakło. The SW-NE direction is represented by the Bełchatów, Szczerców and Złoczew deposits. The Turów deposit, which borders are defined by the Proterozoic crystalline rocks of the Lusatian massif, is classified as tectonic deposit. The SW-SE direction is to some extent related to late tectonic movements of the Mid-Polish aulacogen between the Precambrian East European platform and a young Paleozoic platform. Due to the increased tectonic activity in the areas of grabens (mainly Bełchatów area) and a large number of faults affecting coal-bearing formations, it is recommended to limit the development of UCG installations in the areas of salt domes, grabens and trough. The glaciotectonic deposits include those, whose current form developed under the influence of mechanical pressure of the advancing glacier. They are often in the form of elongated zones, semicircular, horseshoe-like, thrust-faulted or irregularly deformed. The most important include the Muskau Bend (Luk Mużakowski), the Żary area west of Wrocław, deposits near the Rzepin-Świebodzin area in western Poland and others. Due to the significant tectonic deformation, wide angle of lignite seams (e.g. Sieniawa) and discontinuous layers of overburden, glaciotectonic deposits should be excluded from the UCG. The vast majority of Polish lignite is ortho-lignite (low-rank $\mathrm{C}$ coal), that is low rank coal. Its technological parameters are inferior compared to lignite for underground gasification in other countries. This difference must be taken into account when designing underground gasification in Poland. It will affect the technical conditions for conducting the gasification process in Polish deposits.

The Paleogene and Neogene formations in Poland are characterized by the occurrence of poorly cohesive and loose rocks, while the Quaternary overburden is made of waterlogged glacial sediments. At the same time, Paleogene and Neogene sediments are characterized by glacial formations, occurring among others in deep proglacial stream valleys cut into the substrate formations, including upper Tertiary coal-bearing formations. Aforementioned formations are part of the Major Groundwater Reservoirs. The depth of these proglacial stream valleys is up to 400 meters while they are filled with loose sands and river gravels. Proglacial stream valleys were formed in front of melting glaciers and discharged waters in the NW direction, that is into the North Sea. Proglacial stream valleys erode the Tertiary 
coal-bearing substrate up to $3^{\text {rd }}$ group of seams (Ścinawa). Below the Ścinawa deposit, (usually up to approximately 150 meters below sea level) the layers are intact. The occurrence of proglacial stream valleys is disadvantageous for the underground gasification process since they are perfect contact zones for various Tertiary layers and may form uncontrolled gas escape routes. Polish lignite deposits are of large thickness and occur at relatively small depths ranging from tens to hundreds of meters. The coal- bearing profiles are characterized by insulating clay rocks, which favor the gasification process and ensure the tightness against penetrating gases.

Lignite reserves are heavily waterlogged and are in hydraulic contact with the water-bearing levels. Lignite's natural moisture exceeds $50 \%$, which is unfavorable for underground gasification process. The total moisture of coal is important because its excess reduces the calorific value of gas produced as a consequence of energy loss for heating and vaporizing the excess water.

The problem with gasification process is a relatively low calorific value of lignite (below $10 \mathrm{MJ} / \mathrm{kg}$ ). The amount of ash, sulfur and moisture in lignite also contributes to the quality of the gas. Lignite with ash content above $50 \%$ has significantly reduced calorific value (Mastalerz et al. 2011). What is more, ash content above $60 \%$ may inhibit UCG process. The content and ash composition have a significant influence on the course of gasification process, as some minerals can act as catalysts, and others as inhibitors, while the high content of mineral matter causes a decrease in installation efficiency (van Dyk et al. 2001).

The ash content recalculated to dry basis $\left(\mathrm{A}^{\mathrm{d}}\right)$ in lignite deposits is a highly variable parameter. The average value of in the aforementioned deposits is $21.7 \%$ and ranges from $0.4 \%$ to $63.2 \%$.

Table 5. Lignite deposits meeting the conditions for the UCG process (according to Bielowicz and Kasiński 2014; Matl et al. 2015)

Tabela 5. Złoża węgla brunatego spełniające wymagania do podziemnego zgazowania węgla (według Bielowicz i Kasiński 2014; Matl i in. 2015)

\begin{tabular}{|c|l|c|c|c|}
\hline Deposit's area & \multicolumn{1}{|c|}{ Deposit (seam) } & Depth [m] & Thickness [m] & Deposit type \\
\hline \multirow{3}{*}{ Western } & Torzym & 200 & 21.4 & alluvial-tectonic \\
\cline { 2 - 5 } & Pole Sieniawka (Turów mine) & 150 & 15.0 & foredeep \\
\hline \multirow{3}{*}{ Legnica } & Ścinawa-Głogów & 400 & 28.0 & foredeep-alluvial \\
\cline { 2 - 5 } & Legnica Północ (conditionally) & 165 & 21.0 & foredeep \\
\hline \multirow{3}{*}{ Wielkopolska } & Krzywin & 220 & 31.0 & tectonic \\
\cline { 2 - 5 } & Gostyń & 210 & 33.0 & tectonic \\
\cline { 2 - 5 } & Rzetnia & 130 & 15.0 & tectonic \\
\hline \multirow{2}{*}{ Bełchatów } & Węglewice & 155 & 18.5 & tectonic \\
\cline { 2 - 5 } & Kamieńsk & 170 & 18.0 & tectonic \\
\hline \multirow{2}{*}{ Konin } & Lanięta (residue after exploited deposit) & 140 & 36.0 & overlying salt deposit \\
\hline
\end{tabular}


The favorable petrographic composition of lignite, with a strong predominance of components from the huminite group, exceeding (on average) $80 \%$, affecting its high reactivity, high porosity and permeability - the desired characteristics for gasification process - should be emphasized.

When selecting the deposits for underground gasification of lignite, in particular for the proposed location of the pilot plant, all possible limitations must be taken into account. In Poland, there are not enough uninhabited and undeveloped areas. This also applies to national parks, groundwater reservoirs and protected areas (e.g. The Natura 2000 areas) located far away from infrastructure, industrial facilities or mines and communication lines.

Table 5 shows lignite deposits, which meet the criteria for the UCG.

As can be seen, only 10 out of from 166 lignite deposit meet the criteria for the potential development of underground gasification process (Fig. 2).

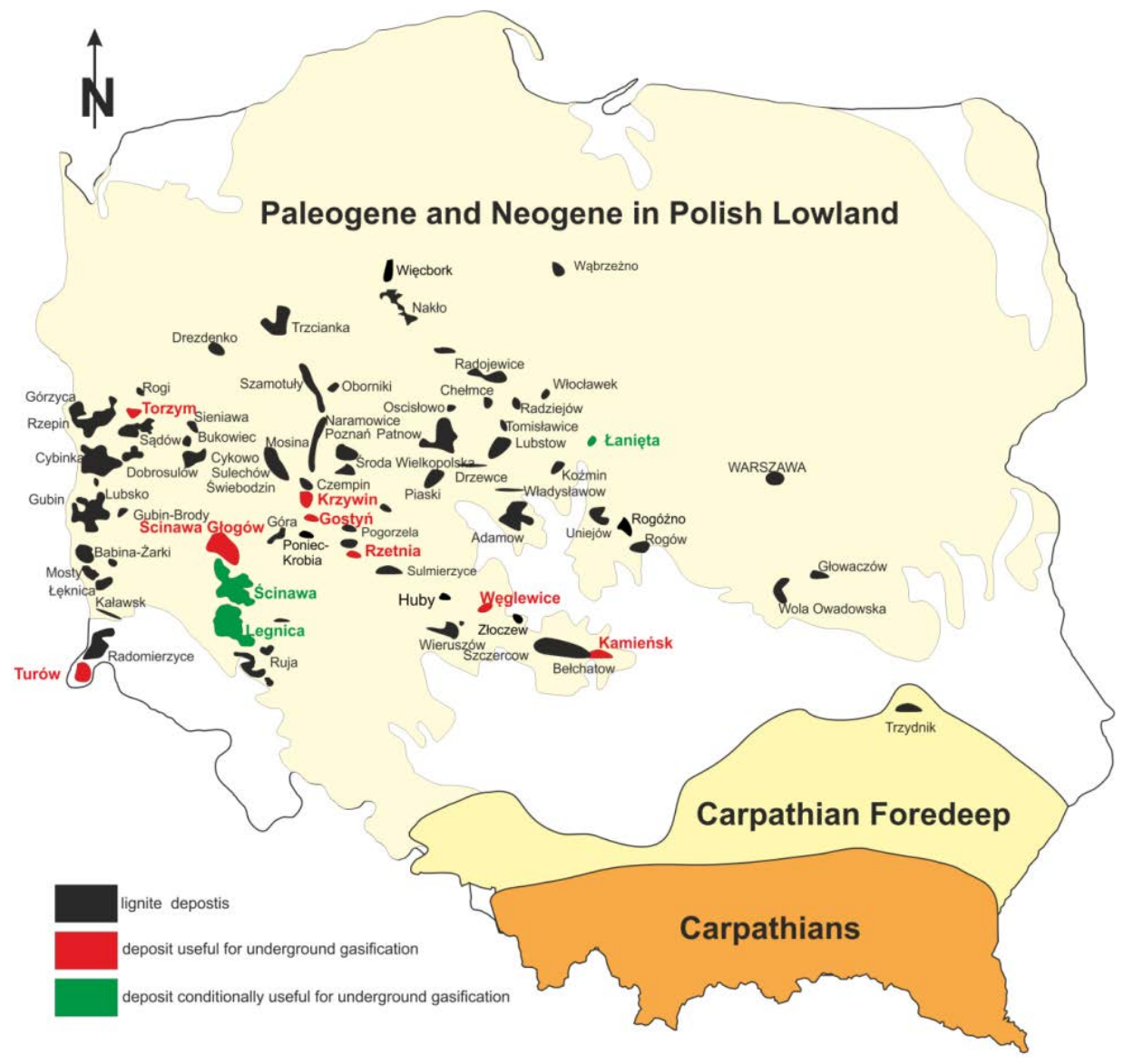

Fig. 2. Location map of lignite deposits useful for underground gasification (according to Bielowicz and Kasiński 2014; Matl et al. 2015)

Fig. 2. Lokalizacja złóż węgla brunatnego przydatnych w procesie zgazowania podziemnego (według Bielowicz i Kasiński 2014; Matl i in. 2015) 


\subsection{The possibility of gasification in the gasifier}

Currently, Polish deposits are associated with specific power plants and the sale of lignite outside this market pretty much does not exist. There is a need to start exploitation of a new deposit, producing lignite solely for gasification purposes.

Only a part of lignite deposits can be used in surface gasification plants. Their selection depends on the accepted criteria for evaluation of lignite for gasification. They were developed in the laboratories of the Institute for Chemical Processing of Coal on the basis of commercial samples supplied by the industry in order to study the exploited lignite deposits (the Turów, Bełchatów and Sieniawa deposits).

Table 6. The key and significant parameters of lignite for gasification in fluidized bed reactor according to the Institute for Chemical Processing of Coal (according to Topolnicka 2011)

Tabela 6. Podstawowe i istotne parametry węgla brunatnego do zgazowania w reaktorze ze złożem fluidalnym, według Instytutu Chemicznej Przeróbki Węgla (wg Topolnicka 2011)

\begin{tabular}{|c|c|}
\hline \multicolumn{2}{|l|}{ Key parameters } \\
\hline Parameter/Unit & Fluidized bed reactor \\
\hline Calorific value $\mathrm{Q}_{\mathrm{i}}^{\mathrm{r}}[\mathrm{kJ} / \mathrm{kg}]$ & $>8000$ \\
\hline Moisture $\mathrm{W}_{\mathrm{t}}^{\mathrm{r}}$ & $<50$ \\
\hline Ash content $\mathrm{A}^{\mathrm{d}}[\%]$ & $<20$ \\
\hline Alkali content $\left(\mathrm{Na}_{2} \mathrm{O}, \mathrm{K}_{2} \mathrm{O}\right)$ & $<0.45$ \\
\hline The temperature of melting ash in a semi-reducing atmosphere $\left[{ }^{\circ} \mathrm{C}\right]$ & $>1100$ \\
\hline Total sulfur content, $\mathrm{S}_{\mathrm{t}}{ }^{\mathrm{r}}[\%]$ & $<2.5$ \\
\hline $\begin{array}{l}\text { The reactivity of char: } \\
\text { towards } \mathrm{CO}_{2} \\
\text { of lignite towards } \mathrm{H}_{2} \mathrm{O}\end{array}$ & $\begin{array}{l}<50 \\
<20\end{array}$ \\
\hline Tar yield content & $<15$ \\
\hline \multicolumn{2}{|l|}{ Significant parameters } \\
\hline Volatile matter content, $\mathrm{V}^{\mathrm{ad}}[\%]$ & $>30$ \\
\hline Carbon content, $\mathrm{C}_{\mathrm{t}}$ ad $[\%]$ & $>45$ \\
\hline Hydrogen content, $\mathrm{H}_{\mathrm{t}}^{\mathrm{ad}}[\%]$ & $3.0-5.5$ \\
\hline Nitrogen content, $\mathrm{N}^{\mathrm{ad}}[\%]$ & $<2.0$ \\
\hline \multicolumn{2}{|l|}{ Ash composition } \\
\hline $\mathrm{SiO}_{2}$ & $25-45$ \\
\hline $\mathrm{Al}_{2} \mathrm{O}_{3}$ & $8-30$ \\
\hline $\mathrm{Fe}_{2} \mathrm{O}_{3}$ & $2.5-20$ \\
\hline $\mathrm{CaO}$ & $3-25$ \\
\hline $\mathrm{MgO}$ & $1.5-4.5$ \\
\hline
\end{tabular}


They were divided into two groups: the key criteria and the relevant criteria (Topolnicka 2012) which must be met for lignite gasification in a pressure reactor with circulating fluidized bed. This technology is distinguished by several features as compared to other commercially available technologies.

It allows for the rational use of lignite, but also allows to reduce the use of lignite and pure oxygen as raw materials for synthesis gas production and subsequent use of intermediate products.

The required values for the criteria are shown in Table 6 .

According to the Institute for Chemical Processing of Coal, the so-called significant criteria are supplementary. They should be taken into account when selecting lignite for surface gasification as they define the essential characteristics of coal that are - in some cases - compatible with the key criteria and may affect the selection of appropriate coal type.

The basic statistics of selected chemical and technological parameters of the Polish deposits are shown in Table 8 .

Under Polish conditions, the ash content is the most restrictive among the key criteria.

The ash content in the majority of Polish deposits usually exceeds the maximum $\mathrm{A}^{\mathrm{d}}$ content $=20 \%$ and - less frequently $-\mathrm{A}^{\mathrm{d}}=25 \%$.

The ash content has a relatively high inverse correlation with calorific value (Bielowicz 2012, 2013b). Such lignite has a low calorific value, which is another eliminating factor. The $\mathrm{A}^{\mathrm{d}}$ level $<25 \%$ is met by only 30 lignite deposits with proven reserves in Poland.

In the vast majority of deposits, lignite is characterized by a high natural moisture content, exceeding the required maximum $\mathrm{M}^{\mathrm{ar}}<50 \%$ (Table 7). The lignite's moisture is technologically reduced prior to entering the gasifier installation.

The basic technological and chemical parameters of lignite largely depend on coal rank and petrographic composition. It determines the carbon $(\mathrm{C})$, oxygen $(\mathrm{O})$, hydrogen $(\mathrm{H})$ and moisture content, which are crucial in the gasification process.

The carbon content in Polish ortho-lignite deposits, recalculated to ash-free basis, is on average around $65 \%$, with a maximum of $77 \%$ in the Turów deposit.

The average volatile matter content recalculated to dry, ash-free basis ( $\left.\mathrm{V}^{\mathrm{daf}}\right)$ is $56.4 \%$.

The ash content, oxide composition and the melting point of ash all play an important role in the gasification process.

The research results on melting temperature of ashes from Polish deposits are presented below:

- The sintering temperature $\left(\mathrm{T}_{\mathrm{S}}\right)$ in an oxidizing atmosphere is in the range $860^{\circ} \mathrm{C}$ (Szczerców) $-1190^{\circ} \mathrm{C}$ (Ościsłowo), while in a reducing atmosphere, this parameter ranges from $770^{\circ} \mathrm{C}$ (Gubin) to $1500^{\circ} \mathrm{C}$ (Gubin).

- The melting temperature (point) in an oxidizing atmosphere ranges from $1200^{\circ} \mathrm{C}$ (Jóźwin) to $1500^{\circ} \mathrm{C}$ (Władysławów).

- The flowing temperature $\left(\mathrm{t}_{\mathrm{c}}\right)$ ranges from $1230^{\circ} \mathrm{C}$ in an oxidizing atmosphere (Jóźwin) up to $>1500^{\circ} \mathrm{C}$ (Szczerców). 
Table 7. The basic statistics of technological and chemical parameters of Polish lignite (according to Bielowicz 2012)

Tabela 7. Podstawowe statystyki parametrów technologicznych i chemicznych polskiego węgla brunatnego (wg Bielowicz 2012)

\begin{tabular}{|c|c|c|c|c|c|}
\hline Variable & Average & Minimum & Maximum & $\begin{array}{l}\text { Standard } \\
\text { deviation }\end{array}$ & $\begin{array}{l}\text { The coefficient } \\
\text { of variation }\end{array}$ \\
\hline Total moisture $\mathrm{M}_{\mathrm{t}}^{\mathrm{ar}}[\%]$ & 51.5 & 36.5 & 63.2 & 4.5 & 8.69 \\
\hline Ash content $\mathrm{A}_{\mathrm{d}}{ }^{\mathrm{b}}[\%]$ & 21.7 & 0.4 & 50.0 & 10.1 & 46.64 \\
\hline Total sulfur content $\mathrm{S}_{\mathrm{t}}^{\mathrm{db}}[\%]$ & 2.22 & 0.13 & 10.76 & 1.42 & 63.70 \\
\hline Calorific value $\mathrm{Q}_{\mathrm{i}}^{\mathrm{r}}[\mathrm{kJ} / \mathrm{kg}]$ & 8178 & 1131 & 20456 & 1596 & 19.52 \\
\hline Gross calorific value $\mathrm{Q}_{\mathrm{S}}{ }^{\text {daf }}[\mathrm{kJ} / \mathrm{kg}]$ & 25639 & 20080 & 29071 & 1914 & 7.47 \\
\hline Volatile matter $V^{\text {daf }}[\%]$ & 55.9 & 48.2 & 64.4 & 2.9 & 5.19 \\
\hline Sand content $\mathrm{p}^{\mathrm{db}}[\%]$ & 7.38 & 0.0 & 81.0 & 11.1 & 149.76 \\
\hline Carbon content $\mathrm{C}^{\mathrm{daf}}[\%]$ & 65.59 & 27.40 & 77.87 & 4.27 & 6.51 \\
\hline Hydrogen content $\mathrm{H}^{\mathrm{daf}}[\%]$ & 5.29 & 2.14 & 8.23 & 0.48 & 9.05 \\
\hline Nitrogen content $\mathrm{N}^{\mathrm{daf}}[\%]$ & 0.9 & 0.40 & 5.46 & 0.47 & 52.25 \\
\hline Oxygen content $\mathrm{O}^{\text {daf }}[\%]$ & 26.56 & 18.10 & 55.38 & 3.61 & 13.60 \\
\hline Porosity n [\%] & 2.81 & 1.04 & 9.41 & 2.23 & 79.42 \\
\hline $\begin{array}{l}\text { Sintering temperature } \mathrm{t}_{\mathrm{S}} \\
{\left[{ }^{\circ} \mathrm{C} \text {, oxidizing atmosphere }\right]}\end{array}$ & 1069 & 860 & 1390 & 106 & 9.92 \\
\hline $\begin{array}{l}\text { Softening point } \mathrm{t}_{\mathrm{A}} \\
{\left[{ }^{\circ} \mathrm{C} \text {, oxidizing atmosphere }\right]}\end{array}$ & 1270 & 1135 & 1581 & 96 & 7.56 \\
\hline $\begin{array}{l}\text { Melting temperature } t_{\mathrm{B}} \\
{\left[{ }^{\circ} \mathrm{C} \text {, oxidizing atmosphere }\right]}\end{array}$ & 1356 & 1210 & $>1500$ & 67 & 4.94 \\
\hline $\begin{array}{l}\text { Flowing temperature } t_{\mathrm{C}} \\
{\left[{ }^{\circ} \mathrm{C} \text {, oxidizing atmosphere }\right]}\end{array}$ & 1388 & 1220 & $>1500$ & 57 & 4.08 \\
\hline $\begin{array}{l}\text { Sintering temperature } \mathrm{t}_{\mathrm{S}} \\
{\left[{ }^{\circ} \mathrm{C} \text {, reducing atmosphere }\right]}\end{array}$ & 1011 & 750 & $>1500$ & 140 & 12.31 \\
\hline $\begin{array}{l}\text { Softening point } \mathrm{t}_{\mathrm{A}} \\
{\left[{ }^{\circ} \mathrm{C} \text {, reducing atmosphere }\right]}\end{array}$ & 1252 & 980 & $>1500$ & 92 & 7.31 \\
\hline $\begin{array}{l}\text { Melting temperature } t_{\mathrm{B}} \\
{\left[{ }^{\circ} \mathrm{C} \text {, reducing atmosphere }\right]}\end{array}$ & 1327 & 1090 & $>1500$ & 85 & 6.37 \\
\hline $\begin{array}{l}\text { Flowing temperature } \mathrm{t}_{\mathrm{C}} \\
{\left[{ }^{\circ} \mathrm{C} \text {, reducing atmosphere }\right]}\end{array}$ & 1353 & 1110 & $>1500$ & 78 & 5.74 \\
\hline Tar yield efficiency $\mathrm{T}^{\mathrm{daf}}[\%]$ & 10.1 & 0.6 & 22.0 & 3.3 & 32.87 \\
\hline Calcium content $(\mathrm{CaO})^{\mathrm{db}}[\%]$ & 2.5 & 0.01 & 19.05 & 2.06 & 82.65 \\
\hline Alkali content $\left(\mathrm{Na}_{2} \mathrm{O}+\mathrm{K}_{2} \mathrm{O}\right)^{\mathrm{d}}[\%]$ & 0.07 & 0.01 & 1.82 & 0.1 & 148.93 \\
\hline Bitumen content $\mathrm{B}^{\mathrm{d}}[\%]$ & 3.0 & 0.2 & 6.7 & 1.3 & 44.02 \\
\hline
\end{tabular}


The fluidized bed gasification process carried out by the Institute for Chemical Processing of Coal in Zabrze and the coal quality requirements included in the "key" and "significant" criteria put certain requirements for coal parameters. They reduce the number of deposits, mainly due to the required amount of certain parameters, such as ash content, calorific value, ash melting point or alkali content.

In Poland, there is a core group of 30 lignite deposits with the ash content ranging from 20 to $25 \%$, which fully meet the criteria for surface gasification.

The lignite reserves in this group are over 11 billion tons, but only around one billion tons can be efficiently used for gasification process. This is because they are needed for both energy purposes and fluidized bed gasification (Matl et al. 2014).

Lignite mining for gasification purposes will need opening new mines in currently unexploited deposits, classified in the Cat. B - Cat. C2, located mainly in the western Poland and in the Legnica region. The currently active open pit mines, the majority of reserves is used to meet energy demand (Matl et al. 2014).

According to the specified criteria, the majority of reserves - that is 4.628 billion tons is classified as $\mathrm{B}-\mathrm{Cl}$, giving the green light to investment. Meanwhile, the prospective deposits, requiring further exploration before further development, are much larger and amount to 22.377 billion tons for the same criteria (Matl et al. 2014).

By analogy to the first group of adjacent deposits, it can be assumed that the lignite quality and its technological features will be similar.

The last group of deposits, with resources amounting to 8.407 billion tons, is not yet fully recognized, outside of the Cat. D1.

The lignite in all other deposits, including the $5^{\text {th }}$ Czempin, $3^{\text {rd }}$ Ścinawa and $6^{\text {th }}$ Tanowo group of seams qualifies for gasification purposes.

Lignite from the $1^{\text {st }}$ Mid-Polish group of seams from the Konin and Radom region, with an average $\mathrm{A}^{\mathrm{d}}$ ash content at $27.53 \%$, should be excluded. This coal is currently exploited in the Konin and Adamów lignite mines.

\section{Summary}

The Paleogene and Neogene coal-bearing formations in Poland are an important national wealth. Thanks to their advantages, they can be mined in open-cast lignite mines, but they are also an excellent raw material for chemical processing, including surface and underground gasification process. Unfortunately, the latter possibility is not used in Poland, and thus represents an excellent, innovative idea to be implemented under the framework of the National Centre for Research and Development project implemented by the AGH University of Science and Technology.

The underground coal gasification is the least likely to be developed. However, this is not due to the lignite quality, but because of the heavy waterlogged deposits and complicated land development, including lack of uninhabitated areas located far away from UCG facilities, unlike in other parts of the world. 
The ortho-lignite $\mathrm{C}$, thanks to its high quality, genetic and chemical properties and above all very low level of transformation (coalification) has preserved the values of primary plant organic matter, from which it originated. Due to the low coalification, it is highly reactive and permeable. It is characterized by limited sinterability associated with gas permeability. What is more, it produces little slag and - as a consequence - ash, which limits the coal loss. Under Polish conditions, both petrographic and maceral composition of coal are highly advantageous, which is essential for both surface and underground gasification processes.

For these reasons, Polish lignite can be used primarily as:

- Energy source (production of electricity and heat).

- Chemical raw material for the surface gasification process and obtaining products and intermediate products for chemical processing.

- Raw material for the underground gasification process after taking into account the Tertiary reservoir properties in Poland.

The chemical and technological advantages of lignite guarantee positive economic effects in all cases. However, in Poland it is only used as an energy source. Taking the geological structure into account, there is sufficient lignite resource base for both gas production and energy purposes. None of the attempts to use lignite for purposes other than combustion have ever been brought to the production stage.

The National Centre for Research and Development project implemented by the consortium and led by the AGH University of Science and Technology aims at expanding the possibilities for using lignite for the benefit of the national economy.

The reservoir and resource base of lignite (ortho-lignite C) in Poland guarantees the realization of this task. It can be used for the surface gasification process in many deposits throughout the country. Thanks to its structure and the chemical and technological composition, it has the characteristics of both power coal and chemical raw material. To sum up, it should be emphasized that Polish lignite is a very good raw material for surface gasification in chemical processing plants. Its reserves are sufficient for the development of this branch of the national economy and should be considered a safeguard for the future. The existing lignite resources, meeting the criteria set by the Institute for Chemical Processing of Coal, allow carrying out the gasification process for a long period of time.

The gasification of lignite in Poland is a completely new opportunity for processing lignite, yet completely unused. This direction meets the criteria of clean coal technologies.

\section{Acknowledgements}

Work performed under task of research No. 3 was funded under the Agreement NCBiR No. SP/E/3/7708/10. This article was supported by the Polish National Science Centre under research project awarded by decision no. DEC-2013/09/D/ST10/04045 and Statutory Research No 11.11.140.320. 


\section{REFERENCES}

Bielowicz. B. 2012. A new technological classification of low-rank coal on the basis of Polish deposits. Fuel 96, pp. 497-510

Bielowicz, B. 2013a. Petrographic composition of Polish lignite and its possible use in a fluidized bed gasification process, International Journal of Coal Geology 116-117, pp. 236-246.

Bielowicz, B. 2013b. Relationship between random reflectance of ulminite B/collotelinite and technological parameters of Polish low-rank coal Fuel 111, pp. 229-238.

Bielowicz, B. and Kasiński, J. 2014. The possibility of underground gasification of lignite from Polish deposits, International Journal of Coal Geology 131, pp. 304-318.

Chmielniak et al. 2015 - Chmielniak, T., Sobolewski, A. and Tomaszewicz, G. 2015. CO2-Enhanced coal gasification. Experience of the Institute for Chemical Processing of Coal. Przemyst Chemiczny 94/4, pp. 16-22.

Higman, C. and van der Burgt M. 2008 Gasification. Second edition. Elsevier.

International Classification of Coal in Seam, 1998 UN-ECE ENERGY/1998/19.

International Energy Agency - IEA, 2015 World Energy Outlook. [Online] Available at: http://www.worldenergyoutlook.org/ [Accessed: 1.10.2016].

Kapusta et al. 2014 - Kapusta, K., Wiatowski, M. and Stańczyk, K. 2014. Simulation of underground coal gasification process in ex-situ experiments. Przegląd Górniczy 70.11, pp. 60-69.

Kasiński et al. 2010 - Kasiński, J.R., Piwocki, M., Sadowska, E. and Ziembińska-Tworzydło, M. 2010. Lignite of the Polish Lowlands Miocene: characteristics on a base of selected profiles. Biuletyn PIG 439, pp. 99-154.

Kasztelewicz et al. 2013 - Kasztelewicz, Z., Zajączkowski, M. and Sikora, M. 2013. Prospects for open-cast mining and gasification technology implementation in the field of brown coal deposits utilization in Poland. Przeglad Górniczy 69/2, pp. 139-147.

Mastalerz et al. 2011 - Mastalerz, M., Drobniak, A., Parke, M. and Rupp, J. 2011. Site evaluation of subsidence risk, hydrology, and characterization of Indiana coals for underground coal gasification (UCG). Final report to CCTR.

Matl et al. 2015 - Matl, K., Kasiński, J. and Bielowicz, B. 2015. Weryfikacja kryterialna bazy surowcowej węgla brunatnego dla potrzeb zgazowania naziemnego i podziemnego z uwzględnieniem gospodarki złożem oraz wytypowaniem rejonu do projektu technologicznego instalacji pilotowej (PZW) AGH Archive Kraków (in Polish).

Matl et al. 2014 - Matl, K., Kasztelewicz, Z., Kasiński, J.R., Bielowicz, B. and Galiniak, G. 2014. Diversification of lignite resource base in Poland for the production of gas using both surface and underground gasification. Przegląd Górniczy 11, pp. 38-46.

Nowak et al. 2011 - Nowak, J., Kudełko, J., Barańska-Buskik, A., Strzelecki, M. and Kobak, P. 2011. Kryteria wymagań z procesów zachodzacych w gazogeneratorze i skałach otaczajacych. Aport dla Konsorcjum, KGHM Cuprum]. AGH Archive (in Polish)

Tajduś et al. 2011 - Tajduś, A., Czaja, P. and Kasztelewicz, Z. 2011. The role of coal in the energy sector and the strategy of Polish lignite mining sector in the first half of XXI century, Górnictwo $i$ Geoinżynieria 35/3, pp. 343-365

Topolnicka, T. 2012. Development of coal gasification technology for high production of fuels and electricity. Final Report Cz. T. B. 1.1.1. AGH Archive Kraków.

van Dyk et al. 2011 - van Dyk, J.C., Keyser, M.J. and van Zyl, J.W. 2001. Suitability offeedstocks for the Sasol-Lurgi fixed bed dry bottom gasification process, Gasification Technologies Conference, Gasification Technologies Council. Arlington, VA, USA, 2001, Paper 10-8.

WCA - World Coal Associacion, 2015. [Online] Available at: http://www.worldcoal.org/sites/default/files/coal_facts_2014\%2812_09_2014\%29.pdf [Accessed: 1.10.2016] 


\title{
PRZYDATNOŚĆ POLSKICH ZŁÓŻ MIĘKKIEGO WĘGLA BRUNATNEGO W CZYSTYCH TECHNOLOGIACH WEGLOWYCH
}

\author{
Słowa kluczowe \\ zgazowanie węgla brunatnego, podziemne zgazowanie węgla brunatnego, zgazowanie fluidalne
}

\section{Streszczenie}

W artykule przedstawiono przydatności polskich złóż węgla brunatnego dla czystych technologii węglowych, głównie zgazowania ze złożem fluidalnym i zgazowania podziemnego. Jednym z kluczowych elementów badań była szczegółowa analiza bazy zasobowej na podstawie ustalonych kryteriów weryfikacji i - jako rezultat - osiągnięcie wiarygodnej oceny przydatności do czystych technologii węglowych z uwzględnieniem warunków ochrony środowiska i sozologicznych. Analiza wykazała, że tylko 10 złóż spośród 166 spełnia kryteria dla potencjalnego rozwoju procesu podziemnego zgazowania. W Polsce istnieje około 30 złóż węgla brunatnego o zawartości popiołu od 20 do $25 \%$, które w pełni spełniają kryteria zgazowania fluidalnego na powierzchni w gazogeneratorze. Zasoby węgla brunatnego w tej grupie to ponad 11 mld ton, ale tylko około jeden miliard ton może zostać efektywnie wykorzystane do procesu zgazowania ze złożem fluidalnym. Biorąc pod uwagę strukturę geologiczną, nie jest wystarczająca baza zasobów węgla brunatnego zarówno do celów produkcji gazu i energii. Żadna z prób wykorzystujących węgiel brunatny do celów innych niż spalanie nigdy nie zostały doprowadzone do etapu produkcji. Zgazowanie węgla brunatnego w Polsce jest zupełnie nową szansą dla przetwórstwa węgla brunatnego, ale zupełnie niewykorzystaną. Ten kierunek spełnia kryteria czystych technologii węglowych.

\section{THE SUITABILITY OF POLISH ORTHO-LIGNITE DEPOSITS FOR CLEAN COAL TECHNOLOGIES}

\author{
Keywords \\ lignite gasification, underground lignite gasification, fluidized bed gasification
}

Abstract

The article presents the suitability of polish lignite deposits for clean coal technologies, mainly fluidized bed gasification and underground gasification. One of the key elements in this study, is a detailed diagnosis of the resource base, its analysis on the basis of the established verification criteria and -as a result - the achievement of a reliable assessment of suitability for highly efficient production of fuels and electric energy through lignite gasification in both surface and underground installations, taking into account both sozological conditions and protected geological sites.

The analysis has shown that only 10 out of from 166 lignite deposit meet the criteria for the potential development of process underground gasification. 
In Poland, there is a core group of 30 lignite deposits with the ash content ranging from 20 to $25 \%$, which fully meet the criteria for surface gasification. The lignite reserves in this group are over 11 billion tons, but only around one billion tons can be efficiently used for fluidized bed gasification process.

Taking the geological structure into account, there is sufficient lignite resource base for both gas production and energy purposes. None of the attempts to use lignite for purposes other than combustion have ever been brought to the production stage.

The gasification of lignite in Poland is a completely new opportunity for processing lignite, yet completely unused. This direction meets the criteria of clean coal technologies. 
